\title{
Detection of Maedi-visna virus in sheep in Nineveh province
}

\author{
S.Y. Al-Baroodi ${ }^{1}$, D.A. Moosa ${ }^{\circledR}$ and M.Y. Al-Attar ${ }^{1}$ \\ ${ }^{1}$ Department of Microbiology, ${ }^{2}$ Department of Internal and Preventive medicine, College of Veterinary Medicine, University \\ of Mosul, Mosul, Iraq
}

\begin{tabular}{l} 
Article information \\
\hline Article history: \\
Received December 4, 2020 \\
Accepted March 21, 2021 \\
Available online November 5, 2021 \\
\hline Keywords: \\
Maedi visna virus \\
Sheep \\
Respiratory signs \\
ELISA \\
Agar gel immune diffusion \\
\hline Correspondence: \\
M.Y.Al-Attar \\
mozahimattar@uomosul.edu.iq
\end{tabular}

Article information

Available online November 5, 2021

\begin{abstract}
This is a primary study in detecting a specific antibody of the Maedi-visna virus (MVV) in blood samples and viral antigen in nasal swabs from sheep. Two hundred and forty nasal swabs and blood samples were collected from sheep of different ages and health statuses in Nineveh province, Iraq. Enzyme-linked immune sorbent assay was used to detect specific antibodies against MVV specific proteins gp135 and p25, Whereas Agar gel immune diffusion (AGID) was used to detect antigens from nasal swabs using specific antibodies against gp135 proteins of MVV. Serological results using ELISA showed the total prevalence of MMV $22.9 \%$ and the highest prevalence of infection in sheep less than one-year-old $36.5 \%$ when compared with older animals $8.4 \%$. Animals that suffering from respiratory problems had a higher prevalence of infection $25.7 \%$ compared with healthy animals 6.9\%. AGID showed an identical reaction between Maedi-visna viruses and specific rabbit antisera with a total infection rate of $12.9 \%$. The highest prevalence of infection was $22.4 \%$ recorded in animals less than one-year-old, the lowest percentage of infection in animals more than two years of age was $1.4 \%$. Animals suffering from respiratory signs also showed high prevalence of infection $13.8 \%$, while the lowest percentage of infection were recorded in healthy animals $4.6 \%$. It has been concluded that the high prevalence of infection rate in sheep less than one-year-old and the animals which suffered from respiratory problems had higher prevalence according to ELISA and AGID testes.
\end{abstract}

DOI: 10.33899/ijvs.2021.129075.1622, (CAuthors, 2022, College of Veterinary Medicine, University of Mosul.

This is an open access article under the CC BY 4.0 license (http://creativecommons.org/licenses/by/4.0/).

\section{Introduction}

Different viruses were affect sheep and goats breeding in the Nineveh governorate, Maedi-visna virus (MVV) is one of that which (a lentivirus that infects sheep and goats) causing encephalitis and arthritis, however is also known as ovine progressive pneumonia (OPP) $(1,2)$. The comparison of nucleic acid sequences of MVV and caprine arthritis encephalitis virus (CAEV) using phylogenetic analysis showed clear indications of cross-species between the two viruses (3). MVV and CAEV are characterized by lifelong persistent infection in host monocytes and macrophages with a long time between the entrance of the virus and the appearance of detectable specific antibodies. The majority of infected sheep and goats do not manifest clinical signs, but remain persistently infected and capable of transmitting the infection and shedding the virus (4). The clinical signs of these viruses are paralyzing meningoencephalitis, progressive pneumonia (which are the main signs of MVV infection), chronic arthritis, and synovitis (which are the main symptoms of CAEV infection). Encephalitis occurs primarily in newborn animals between 8 and 24 weeks following CAEV infection (5). The agar gel immunodiffusion test (AGID) was used to diagnose infection (6). Indirect and competitive enzyme-linked immune sorbent assays (I-ELISAs and c-ELISA, respectively) were used to determine anti-MVV or antiCAEV antibodies in the sera of animals (7). A few of the I- 
ELISAs showed high sensitivity and specificity against a standard of comparison; one c-ELISA showed high sensitivity and specificity in both sheep and goats in the USA, suggesting that this one test could be used for both MVV and CAE (8).

\section{Materials and methods}

\section{Animals and samples collection}

Two hundred forty sheep of different ages, and breeds reared in different regions in Nineveh province, Iraq were studied herein. Some of the animals were suffering from nasal discharge, loss of appetite, cough, and dyspnea, while others appeared clinically healthy. Blood samples and nasal swabs were collected from each animal. Blood samples were clotted after being placed in $25^{\circ} \mathrm{C}$ temperature for 15 minutes. Then the serum was separated by centrifuging at $1500 \mathrm{rpm}$ for 10 minutes and stored at $-20^{\circ} \mathrm{C}$ (9). The nasal swabs were collected and then added to $5 \mathrm{ml}$ of sterile phosphate buffer saline to a glass tube and centrifuged at $6000 \mathrm{rpm}$ for 1 hour. The sediment was discarded and the supernatant was stored at $-20^{\circ} \mathrm{C}(10)$.

\section{Enzyme-linked immune sorbent Assay (in direct ELISA)}

I-ELISA (ID. Vet. VISNAS -5P) was used according to the manufacturer's instructions to investigate the specific IgG immunoglobulin against peptides from the MVV/CAEV TM, gp135 and p 25 proteins

\section{Agar gel diffusion}

The agar gel diffusion test was performed as double diffusion in agar gel according to (11) to detect viral antigens in nasal swabs using specific antisera. Agar gel immunodiffusion test kits for diagnosing Maedi-Visna (RAI0260) in sheep consisted of precipitating antiserum to the glycosylated envelope polypeptide (gp 135) antigen of MVV.

\section{Statistical analysis}

The variations in the prevalence of MVV between the ages of animals and the animal's status were evaluated by employing two-sided Chi-square and Fischer's exact test in IBM-SPSS statistics version19 program.

\section{Results}

The result of serological investigations of Maedi-visna virus antibodies using ELISA test showed $22.9 \%$ prevalence of infection with Maedi-visna virus. The prevalence of infection was higher in sheep less than oneyear-old 36.5\% when compared with older sheep 8.4\% (Table 1). A higher prevalence of infection was recorded in animals suffering from respiratory symptoms $25.7 \%$ when compared with healthy animals $6.9 \%$ (Table 2). The results of the agar gel diffusion analysis showed identical positive reaction between Maedi-visna viruses and specific rabbit antisera. The percentage of total infection rate was $12.9 \%$, and animals less than one year of age showed the highest rate of infection $22.4 \%$, and the lowest percentage rate of infection was recorded in animals more than 2 years old $1.4 \%$ (Table 3). Results of the agar gel diffusion analysis showed a higher prevalence of infection in animals with respiratory signs $13.8 \%$, while the lowest percentage of infection was recorded in healthy animals $4.6 \%$ (Table 4).

Table 1: Percentage of infection with Maedi-visna virus according to age of the animals using ELISA

\begin{tabular}{lcc}
\hline Age & No. blood samples & No. positive $(\%)$ \\
\hline$>1$ year & 107 & $39(36.5)^{\mathrm{a}}$ \\
1 -2 years & 62 & $10(16.7)^{\mathrm{b}}$ \\
$<2$ years & 71 & $6(8.4)^{\mathrm{c}, \mathrm{b}}$ \\
\hline Total & 240 & $55(22.9)$ \\
\hline
\end{tabular}

Different latter were significantly different at $\mathrm{P}<0.05$.

Table 2: Percentage of infection with Maedi-visna virus by using ELISA according to health status of the animals

\begin{tabular}{lcc}
\hline Health status & Number of blood samples & Number of positive samples (\%) \\
\hline Suffering from respiratory symptoms & 167 & $43(25.7)^{\mathrm{a}}$ \\
Clinically healthy animals & 173 & $12(6.9)^{\mathrm{b}}$ \\
\hline Total & 240 & $55(22.9)$ \\
\hline
\end{tabular}

Different latter were significantly different at $\mathrm{P}<0.05$.

Table 3: Percentage of infection with Maedi-visna virus by using AGID according to age of the animals

\begin{tabular}{lcc}
\hline Age & Number of nasal swabs samples & Number of positive samples(\%) \\
\hline Less than 1 year & 107 & $24(22.4)^{\mathrm{a}}$ \\
1 -2 years & 62 & $5(8.1)^{\mathrm{b}}$ \\
More than 2 years & 71 & $1(1.4)^{\mathrm{c}, \mathrm{b}}$ \\
\hline Total & 240 & $31(12.9)$ \\
\hline
\end{tabular}

Different latter were significantly different at $\mathrm{P}<0.05$. 
Table 4: percentage of infection with Maedi-visna virus by using AGID according to health status of the animals

\begin{tabular}{lll}
\hline Health status & Number of nasal swabs samples & Number of positive samples (\%) \\
\hline animals suffering from respiratory symptoms & 167 & $23(13.8)^{\mathrm{a}}$ \\
Clinically healthy animals & 173 & $8(4.6)^{\mathrm{b}}$ \\
\hline Total & 240 & $31(12.9)$ \\
\hline
\end{tabular}

Different latter were significantly different at $\mathrm{P}<0.05$.

\section{Discussion}

The detection of Maedi-visna virus antibodies in sheep confirms the infection. The virus can be replicated in cells which may be restricted, thus limiting viral antigen production. Limited antigen expression will not induce a good immunological reaction, and some animals may stay give ELISA-negative, despite carrying the virus being virus positive (12). The results of the current study showed a high prevalence of infection in young animals, while several studies that aimed to determine the relationship between infection rate and animal age, Kita et al., (13) recorded a high prevalence of infection in adult sheep more than 5 years old. The difference in prevalence of infection among different ages was seen but not proven because of inadequate numbers, while Ernst et al. (14) reported an infection rate of $18 \%$ in sheep less than 2 years old and Giangaspero et al. (15) reported 6\% total infection rate in Syrian Awassi sheep. Varea et al. (16) indicated a high prevalence of infection in sheep up to 3 years old when compared with sheep less than a year old. Luqman and Cumali (5) recorded a high prevalence of infection in adult animals in Erbil province, Iraq. The differences among studies can be explained by the differences in animal management methods, the sources of the animals (local or imported breeds), and the presence of stress factors like shipping or the presence of a secondary infection.

The highest prevalence rate of infection was recorded in animals suffering from respiratory symptoms when compared with healthy animals, in line with the results of many other researchers. Luqman and Cumali (5) recorded a high prevalence of Maedi-visna virus in animals suffering from respiratory symptoms. Esperanza et al. (17) showed a relationship between respiratory and other clinical signs and Maedi-visna seropositivity. The agar gel diffusion results showed an identical reaction between Maedi-visna viruses and specific antisera. The total infection rate was $12.9 \%$, and animals younger than one-year-old and those suffering from respiratory symptoms showed the highest infective rates. Agar gel diffusion has been used by several researchers with great success in detecting viral antigens and antibodies; for example, Alluwaimi et al. (18), who used AGID to detect viral antibodies in Saudi Arabian sheep. Varea et al. (16) used ELISA and AGID in their comparative study of these techniques to detect viral antibodies. Carole et al. (19) successfully compared ELISA and AGID in detecting viral antibodies. Other researchers successfully investigated viral antigens in lymphoid tissue in sheep suffering from respiratory signs by using another technique (PCR, IHC) (20), while Reyburn et al. (21) used P24 antigens as a method to detect viral antigens. The presence of seropositive sheep within herds can be explained by the importation of feedlot sheep, poor quarantine measures, the lack of monitoring of sheep flocks to and from unobserved fringe seropositive Maedi-visna virus polities, and contact between unhealthy and healthy animals. This study was conducted in the presence of Maedi-visna virus infection in the polities adjoining Iraq (Iran, Turkey, and Syria) $(4,22)$.

\section{Conclusions}

Using ELISA test to detect antibodies in serum samples against MVV and AGID to detect viral antigen in nasal swabs showed high prevalence of infection rates in sheep less than one-year-old and animals suffering from respiratory problems.

\section{Acknowledgment}

The authors wish to thank the College of Veterinary Medicine/ University of Mosul for financially supporting this work; the laboratory of veterinary teaching hospital, for their support and the animals' owners for their cooperation.

\section{Conflict of interest}

The Authors declare no conflict of interests of the manuscript.

\section{References}

1. Al-Baroodi SY. Isolation and pathogenesis of sheep pox virus in Nineveh governorate. Iraqi J Vet Sci. 2009.23(1):21-26. [available at]

2. Thormar H. Maedi-visna virus and its relationship to human immunodeficiency virus. AIDS Rev. 2005;7(4):233-45. [available at]

3. Omme YL, Ouardani M, Lévesque V, Bertoni G, Simard C and Pisoni G. Molecular characterization and phylogenetic analysis of small ruminant lentiviruses isolated from Canadian sheep and goats. Virol J. 2011;3(8):271. DOI: www.doi.org10.1186/1743-422X-8-271

4. Mohammad A, Karapınar Z. Seroprevalence of visna-maedi virus (VMV) and border disease virus (BDV) in van province and around. Arq Bras Med Vet Zootec. 2018;70(4):1029-1035. DOI: 10.1590/1678-4162-10005

5. Luqman AH, Cumali O. Serological investigation of maedi-visna in sheep with chronic respiratory disease in Erbil, Iraq. Ataturk Univ. Vet Bil Derg. 2017;12(3):227-234. DOI: 10.17094/ataunivbd.295120 
6. Oguma K, Chiaki T, Ryo H, Atsushi K, Jun S, Masanobu G, Hiroshi S. Isolation of maedi/visna virus from a sheep in Japan. J Vet Med Sci. 2014;76(2):211-218. DOI: 10.1292/jvms.13-0269

7. Brinkhof J, Van Maanen C. Evaluation of five enzyme-linked immunosorbent assays and an agar gel immunodiffusion test for detection of antibodies to small ruminant lentiviruses. Clin Vacc Immuol. 2007;14(9):1210-1214. DOI: 10.1128/CVI.00282-06

8. Rodolphe M, Eva Van M, Christian Q, Nadjah RA, Ann BC, Nick DR. Comparative analysis of different serological and molecular tests for the detection of small ruminant lentiviruses (SRLVs) in Belgian sheep and goats. Viruses. 2018;10(12):696. DOI: 10.3390/v10120696

9. Rai A. Methods in veterinary virology. Indian Vet Res Inst. 2005;1:50-52. DOI: 10.1016/j.cvex.2004.09.009

10. Rai A. Laboratory manual of cell culture and animal virology. Indian Vet Res Inst. 2008;10:8-12. [available at]

11. Herrmann LM, William PC, Katherine LM, Travis CM, Melinda MH, Gregory SL, Donald PK. detection of serum antibodies to ovine progressive pneumonia virus in sheep by using a caprine arthritisencephalitis virus competitive-inhibition enzyme-linked immunosorbent assay. Clin Diagn Lab Immuol. 2003;10(5):862-865. DOI: 10.1128/CDLI.10.5.862-865.2003

12. Berriatua E, Alvarez V, Extramiana B, González L, Daltabuit M, Juste R. Transmission and control implications of seroconversion to MaediVisna virus in Basque dairy-sheep flocks. Prev Vet Med. 2003;60(4):265-279. DOI: 10.1016/s0167-5877(03)00163-6

13. Kita J, Cutlip RC, Kempski W, Sacks J. Survey for antibodies against maedi-visna in sheep in Poland. Pol Arch Weter 1990,30:5-11. [available at]

14. Peterhans K, Greenland T, Badiola J, Harkiss G, Bertoni G, Amorena B, EliaszewiczM, Juste R. Routes of transmission and consequences of small ruminant lentiviruses (SRLVs) infection and eradication schemes. Vet Res. 2004;35 257-274. DOI: 10.1051/vetres:2004014

15. Giangaspero $M$, Tabbaa D, Nishikawa $H$, and Vanopdenbosh E. Epidemiological survey of the Maedi Visna (MV) virus in Syrian Awassi sheep. Rev Elev Med Vet Pays Trop. 1993;46(3):431-434. [available at

16. Varea R, Monleo E, Pacheco C, Luja L, Bolea R, Vargas MA, Van Eynde G, Saman E, Harkiss G, Amorena B, Badiola J. Early detection of maedi-visna (ovine progressive pneumonia virus seroconversion in field sheep samples. Vet Diagn Invest. 2001;13:301-307. DOI: 10.1177/104063870101300404

17. Esperanza GL, Nuria B, Ana D. Maedi-Visna virus: current perspectives. Vet Med. 2018;9:11-21. DOI 10.2147/VMRR.S136705

18. Alluwaimi AM, Abu E, Hassanein MM. Caprine arthritis-encephalitis antibodies in indigenous sheep in Saudi Arabia. Reveu Elev Med Vet Pays Trop. 1990;43(4):444-445. [available at]

19. Carole LS, Milton RB. An enzyme-linked immunosorbent assay for detection of antibodies to maedi-visna virus in sheep II. Comparison to conventional agar gel immunodiffusion test. Can J Vet Res. 1990;54:451-456. [available at]

20. Preziuso S, Magi GE, Mari S, Renzoni G. Detection of visna maedi virus in mesenteric lymph nodes and in other lymphoid tissues of sheep three years after respiratory infection. Vet Med. 2013;8(7):359363. DOI: $\underline{10.17221 / 6916-V E T M E D}$
21. Reyburn H, Roy J, Blacklaws BA, Sargan D, McConnell I. Expression of maedi-visna virus major core protein, p25: development of a sensitive p25 antigen detection assay. J Virol Meth. 1992;37:305-320. DOI: 10.1016/0166-0934(92)90031-8

22. Sakhaee E, Khalili M. Serological study of Maedi-Visna virus among sheep flocks in Kerman province of Iran. Iran J of Virol. 2010;4(1): 29-33. DOI: $\underline{10.21859 / \text { isv.4.1.29 }}$

\section{الكشف عن فايروس Maedi visna في الأغنام في محافظة نينوى}

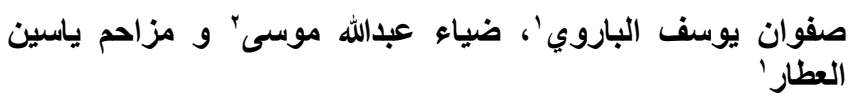

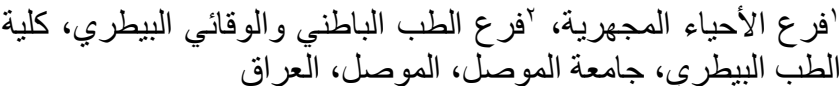

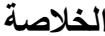

تعد هذه دراسة من الدراسات الأولية في الكثف عن الأجسام

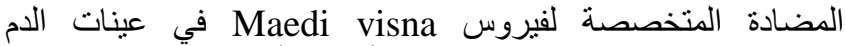

و المستضد الفيروسي في مسحات الأنف للأغنام. تم جمع مائتين

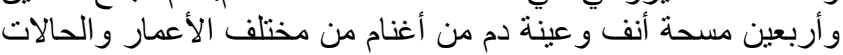

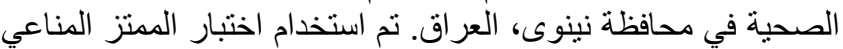

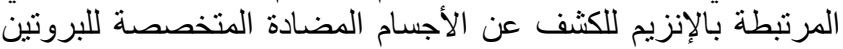

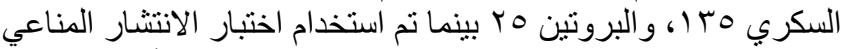
على هلامة الاكار للكثف عن اليزون هن المستضدات من مسحات الأنف باستخدام

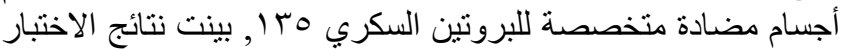

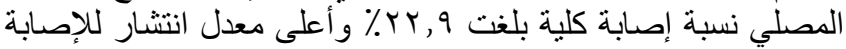

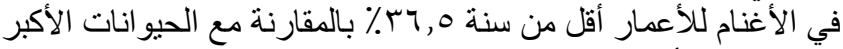

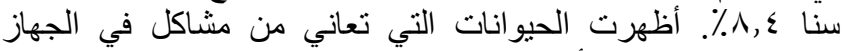

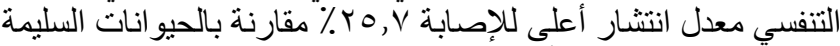

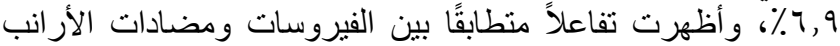

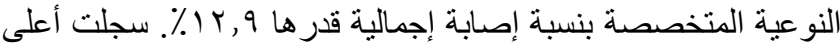

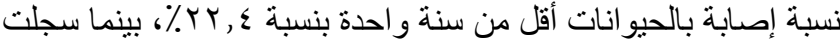

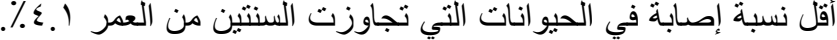

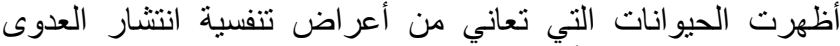

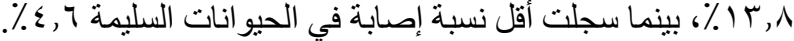

